\title{
Transnational Veto Players and the Practice of Financial Reform
}

\author{
Tsingou, Eleni
}

Document Version

Final published version

Publication date:

2013

\section{License \\ CC BY-NC-ND}

Citation for published version (APA):

Tsingou, E. (2013). Transnational Veto Players and the Practice of Financial Reform. Paper presented at International and European Economic Governance, Frederiksberg, Denmark.

Link to publication in CBS Research Portal

\section{General rights}

Copyright and moral rights for the publications made accessible in the public portal are retained by the authors and/or other copyright owners and it is a condition of accessing publications that users recognise and abide by the legal requirements associated with these rights.

\section{Take down policy}

If you believe that this document breaches copyright please contact us (research.lib@cbs.dk) providing details, and we will remove access to the work immediately and investigate your claim. 


\title{
Transnational Veto Players and the Practice of Financial Reform Eleni Tsingou
}

\begin{abstract}
Policy processes in transnational settings are shaped by actors whose approval and consent are required for reform to take place. These 'transnational veto players' frame and delimit policy options. The concept of 'transnational veto players' is developed through an empirical analysis of global reforms in the regulatory treatment of large financial institutions deemed 'too big to fail'. Actors debating and developing policy on 'too big to fail' may have formal defined constituencies, as regulators, academics or lobbying organisations, but in their transnational interactions they are also informed by a diffuse constituency of peers through their multiple associations within policy communities. These interactions determine which policy ideas are permissible and how they are adopted. The 'too big to fail' case shows how reform activity to curtail the risks posed by large financial institutions may also inadvertently strengthen their position as transnational veto players.
\end{abstract}

\section{Introduction}

The onset of the global financial crisis in 2007-2008 sparked a plethora of reform proposals, backed by political rhetoric, concrete regulatory policy goals and a revamped global institutional framework. Part of this activity was aimed at altering a long standing but implicit contract between financial institutions and the state, one that could be summarised as 'tails, the bank wins, heads, the taxpayers lose'. Some years later, however, there is a degree of sobriety about the content and pace of reform which do not match early publicly stated expectations, including by the G-20 (cf. Helleiner 2011). Instead, the process of reform is best characterised as incremental although there is notable variation in the regulatory initiatives and outcomes across nations and issue areas (Moschella and Tsingou 2013a).

One area which has experienced significant reform activity but arguably modest overhaul is the regulatory treatment of financial institutions deemed 'too big to fail' (TBTF). TBTF refers to an ex post assessment of the significance of a financial institution to the system as a whole, based on its size and the connectedness and complexity of its activities, but is also used as a general term in discussions about size and function in the financial sector. As the financial crisis showed, in turbulent 
times, size, function, exposure and risk are re-evaluated at the national level, especially in cases of bank failures or near-failures. Decisions about whether an institution is TBTF become a matter for national authorities. Yet the global activity and systemic implications of a failure make TBTF an issue to be tackled in a transnational context, based on the importance of coordinating risk assessments and harmonising standards for large financial institutions. These tasks were assigned to the Baselbased Financial Stability Board (FSB) in collaboration with the Basel Committee on Banking Supervision (BCBS). The article traces the genealogy of ideas on TBTF post-crisis and outlines that they evolved into two specific lines of reform developed and coordinated by the FSB: first, the production of criteria that identify Global Systemically Important Financial Institutions (G-SIFIs), and second, the creation of standards for the orderly resolution of failing institutions through 'living wills' and resolution regimes.

In showing how the ideational parameters for addressing TBTF are defined in a transnational context, the article explores the role of different actors and their interactions in the practice of reform. To do so, the article develops the concept of 'transnational veto players', explaining that in their transnational interactions too actors can act to block change. What animates blockage is not informed by formal affiliations alone but is ideational, and shapes the frames of debate and thus the range of reform options.

The concept of 'transnational veto players' is adapted from the domestic and comparative politics literature. The notion of veto players was most extensively explored by Tsebelis $(2000 ; 2002)$ and applied across political systems to investigate policy stability. The concept brought agents to the fore of the analysis: 'institutions are like shells and the specific outcomes they produce depend upon the actors that occupy them' (Tsebelis 2002, 8). Though the concept was developed as part of a rational choice approach with an emphasis on prediction of policy outcomes, it can be usefully applied to transnational settings where, as a descriptive concept, it directs our attention to the actors operating distinctly from their principals and presenting potential blockage points through a preselection of policy choices.

The actors that practice financial reform in the global arena can be understood as 'transnational veto players' whose approval is needed for change to take place, be it formal rule change, or change in the mode of policy-making. Their formal affiliation (public or private) does not determine their regulatory preferences. These actors can have official roles and be bound by domestic accountability mechanisms, or can be lobby groups and financial institutions reporting to members and shareholders; but when they are involved in discussions about global standards, their constituencies are not limited by their formally defined responsibilities. Instead, their associations in a transnational 
context in standard-setting fora and in formal and informal consultation settings where reform options are discussed, mean that there are additional peers and interlocutors who need to be satisfied by the spectrum of reform options. Whether they have formal agenda-setting powers or not, the actors in transnational settings need to find common ground on the plausibility of reform options - proposals that do not fit in that range are ignored or blocked. The article explains that this leaves the reform process in a 'muddling through' mode (Lindblom 1959), with actors in transnational settings operating as veto players and settling on which expert ideas influence the reform agenda (cf. Lindvall 2009). The ideational blockages constrain wholesale rethinking and lead to modest departures from the status quo. This is not to equate conservative bias with the absence of reform - as the case of TBTF shows, the practice of financial reform can encompass high levels of activity but within pre-defined parameters which maintain and even strengthen the position of actors whose risk potential reform aims to tame.

The article proceeds as follows. The next section expands on the concept of 'transnational veto players' and situates the conceptual contribution in explanations of institutional and ideational change. The subsequent section systematises the role of transnational veto players in relation to a muddling through policy mode and defines the range of what constitutes change in the field of TBTF. The article continues with an empirical section on the regulatory treatment of TBTF after the crisis. The section focuses on the development of policy ideas on TBTF through key papers and speeches; this is supplemented by a series of research interviews with practitioners in the official and private sector involved in the reform process at the national level, as well as standards-setters in Basel in the period 2008-2012. The article concludes with some observations on why studying actors as veto players and analysing their blockage potential is useful in explaining policy interactions in transnational settings and understanding the content and practice of reform that they generate.

\section{Stability and reform after the financial crisis: actors and policy modes}

When studying change and reform in global finance, insights from domestic and comparative politics can be especially valuable. From literature focusing on the domestic level, for instance, we know that understanding the content and timeframe of institutional change means looking at identifiable established interests. Significant advances have been made within the framework of traditional institutionalisms. Moving beyond the focus on institutions as self-reinforcing equilibria and path dependence processes (Pierson 2000), scholars have demonstrated that major change may well occur outside of critical junctures (Streeck and Thelen 2005). More recent studies have also offered 
an inventory of commonly observed patterns of gradual institutional change that may be consequential as causes of other outcomes (Mahoney and Thelen 2010). At the same time, important insights have been developed within the realm of sociological and discursive institutionalism, where attention was given to the role that ideas have on the process of institutional change (Schmidt 2002; Blyth 2002). In particular, these studies have disclosed the process of preference formation and the enabling, rather than solely constraining, nature of institutions.

The literature has also drawn, implicitly, on the idea that 'veto players' can block reforms they do not like or find suitable through their formal representative authority (Tsebelis 2000; 2002), and that coalitions of party-political and business interests can stop reforms through persuasion and pay-offs. Developed in the rationalist tradition to understand policy outcomes across political systems, the veto players literature suggests, first, that 'veto players are individual or collective decision-makers whose agreement is required for the change of the status quo' (Tsebelis 2000, 442). Second, it stresses that the number of veto players matters, as multiple veto players slow the process of change (Tsebelis 2000, 442-446). Third, the literature points to the sequence of veto players, rendering some agenda-setters required to make any proposals for change acceptable to other veto players (Tsebelis 2002, 2-3). Finally, 'veto players per se do not produce any particular political results. They just slow down or facilitate policy changes' (Tsebelis 2000, 463). The language of veto players and also, change agents, is especially useful in understanding the actors and their strategies in a reform process (Moschella and Tsingou 2013b). Change agents can be open advocates of particular reform proposals (or more covert supporters engaging in coalitions), whereas veto players may work to oppose change or endorse limited slow change in order to preserve the status quo and retain privileges. They work against a background of an 'exceptionally strong tendency to cast even the most severe and unexpected problems as amenable to be solved by an incremental modification of existing best practices' (Porter and Ronit 2006, 51).

This article suggests that the concept of veto players is also useful when the analysis moves beyond a domestic political setting and the narrower confines of legislative, bureaucratic and judicial politics. Specifically, it argues that we find transnational veto players in the practice of financial reform. On the face of it, the concept of a transnational veto player appears logically inconsistent. Veto players are located in defined constituencies that can be found in formal polities; the autonomy from a formal polity implied by 'transnational' should denude the actor of their veto powers. The concept can also carry assumptions about fairly straightforwardly defined interests; while deriving strategies from interests at the domestic level may be a possible task, in a transnational context, constituencies are diffuse and such clarity about interests is diluted. Indeed, 
analyses of transnational actors point that 'their behavior is in large part defined by the institutional tool that they do not have: formal veto power over government policy' (Béland and Overstein 2010, 4).

Yet, this article claims that transnational veto players exist. The transnational context provides a setting where standards are produced in formal institutional fora and technocratic governance prevails. Actors operating transnationally do so because of market size or resources (be they public or private) but once there, their interactions are defined by ideational parameters. Transnational veto players share some of the key characteristics defined above with domestic veto players, and the concept is a useful analytical device to account for the dynamics, conflicts and compromises in transnational interactions. An important difference is that a transnational veto player need not be an actor with formal authority or a pre-defined position in the policy-making process.

There is a range of actors who have decisive roles within defined domestic and international polities that also belong to policy networks that can only be understood as transnational. Take, for example, the FSB and the BCBS; their members are central bankers and regulators of large advanced and, following the crisis, emerging economies. Within their own constituencies they have the potential to block institutional change as part of broad and narrow policy compromises. Yet these actors, the regulators and central bankers, are also involved in policy discussions - and much wrangling over the winners and losers of reform - through transnational interactions. The terms of those debates cannot be derived from domestic compromises and interests alone but are informed by associations in formal and informal transnational fora. In this context, preferences with respect to reform and change are, in principle, a matter for empirical investigation. While there are no defined constituencies in transnational settings, informally, networks of peers and interactions within transnational policy networks create a transnational constituency of stakeholders, a diffuse constituency. In this example, the FSB and the BCBS provide the institutional framework and reform location. The actors' reform positions thus depend not solely on their national roles but on their interactions within the BCBS and the FSB, as well as their informal dealings with global financial institutions, lobby groups, international organisations, and academic experts. Together, these interactions help delimit the reform options and crystallise actor preferences; in the process, all these actors act as transnational veto players, delineating the thinkable and credible and able to block reform beyond that range.

Traditional explanations of transnational policy interactions based on transgovernmental networks, private authority and lobbying, and experts, have tended to treat these different actors as discreet entities. A focus on transgovernmental networks provides an account of the mechanics of 
transnational standard-setting but can overstate the intergovernmental character of interactions (see, for instance, Simmons 2001; Drezner 2007) which is less useful in times of crisis when the preferences of actors may be in flux. It might also underplay the role of the private sector (Baker 2012) by limiting its influence to consultation processes and not taking into account the informal character of interactions between official and private sector actors. Additionally, in the practice of financial reform, transgovernmental networks face constraints based on political and electoral cycles; the financial crisis has not altered the belief among regulators that governments have a short-term vision that can prevent good policy. (1) Elsewhere, explanations based on private authority work particularly well for studies of specific issue areas such as accounting (Botzem 2012; Büthe and Mattli 2011) but are less salient in 'messier' financial governance fields like banking (for an analysis of the limited influence of straight lobbying in global banking, see Young 2012). A focus on the private sector becomes most fruitful in evaluating the role and types of regulatory capture, an approach that goes beyond discreet categories of public and private (Pagliari 2012). Accounts focusing exclusively on private authority and lobbying to explain transnational regulatory outcomes are also limited by private actors' reduced resources following the financial crisis, as well as their disputed formal access to policy-making processes. Finally, explanations based on good science (Marcussen 2009) and epistemic communities (Haas 1992) as the providers of key ideas for policy reform are limited by the failure of prevailing expertise in the run-up to the crisis. Initiatives such as the Institute for New Economic Thinking which was created with the explicit task of bringing new ideas into Economics are still in their infancy and experts who might act as ideational change agents need to consolidate their position in policy networks. So while it is possible to identify experts promoting good science, this is done through engagements in policy networks and not in isolation. Table 1 provides a summary of the formal constituencies, reform policy goals and main constraints of the actors in focus in these explanations.

Table 1 here

As the table shows, all three explanations can offer significant insights on the preferences actors articulate in a transnational setting as well as the reasons they may want more or less change and the constraints they face in pushing their reform goals. But these explanations miss a dynamic element of interaction between different actors once removed from the formal constituencies. This can be introduced through the notion of transnational veto players which also enables us to move 
beyond rigid understandings of enduring consensus and resilience of transnational policy networks, and consider the nature of change actually taking place. Away from the formal constituency arena, the focus is less on resources and political constraints and more on the potential for ideational vetoes. The actors operate as transnational veto players primarily through their ideational activities and the possibility they have to persuade and delimit options (cf. Béland and Overstein 2010). There is thus scope for conflict, compromise and blockage in determining which policy reforms are credible.

A concept that usefully explains the mode of policy resulting from such interactions is Lindblom's 'muddling through' (1959). Sometimes associated with a conservative understanding of incrementalism as favouring the status quo over change, it is nevertheless relevant in explaining the practice of reform (Rothmayr Allison and Saint-Martin 2011). Although developed by Lindblom in relation to studies of public administration, its application to other levels of governance is appropriate, especially as the politicisation of finance following the crisis subsides and the confrontational blame games of the domestic arena are diluted.

'Muddling through' breaks with assumptions that 'a rational-comprehensive approach' can be pursued when dealing with complex policy problems. This approach implies that policy modes can match policy goals and that those in charge of policy have both the information and the resources to explore all possible options and differentiate between facts and values. For Lindblom, however, it does not describe nor explain policy-making. By focusing on 'muddling through', he explains that policy processes follow the method of 'successive limited comparisons', 'building out from the current situation, step-by-step and by small degrees' (Lindblom 1959, 81). This results in rational compromise, with an emphasis on trial and error and minimising the cost of change.

Muddling through is an apt way to account for the practice of reform in the aftermath of the crisis and the mode of policy when transnational veto players are at play. This understanding of policy processes fills the gap, in a post-crisis context, of alternative explanations aiming to match formal constituencies, policy goals and constraints as outlined above.

Figure 1 here

As Figure 1 shows, policy goals by discreet groups of actors can be analysed along two axes. One axis identifies whether policy actors have defined or diffuse constituencies according to traditional 
explanations and the other traces the policy mode. We can thus distinguish between transgovernmental networks, private authority and experts and their formal policy goals. In the aftermath of the crisis, some reform proposals put forward by experts for implementation by transgovernmental networks assume a rational-comprehensive mode of policy; one example of such a reform idea is the development of an additional layer of financial governance, distinct from policymaking and private interest, a 'Sentinel' which could evaluate financial system activity on behalf of the public (Barth, Caprio and Levine 2012). Yet when we analyse the practice of reform, we see few such ideas debated in policy fora. This is not to suggest that private actors control the agenda but rather, that experts, private actors and transgovernmental networks together follow a managed reform process based on their interactions and ideational blockages. In Figure 1, this is the space populated by an explanation based on actors operating as transnational veto players. The case of TBTF outlined in the subsequent sections illustrates this.

\section{Policy goals and reforming TBTF: Transnational veto players and the politics of 'muddling through'}

This article's assessment of TBTF reforms is that they are extensive yet modest. Admittedly, analytical (and practical) definitions of what constitutes radical, incremental or mere symbolic change are difficult to establish. For the purposes of this analysis, a 'radical' process of reform is one that comprehensively re-evaluates the role of finance and redefines the functions of banks (cf. Rethel and Sinclair 2012), and one that significantly reduces the threat to the sovereign posed by the size of financial institutions: as one public official put it, 'banks should not hold the state to ransom'. (2) Instead, the policy process of establishing global standards for TBTF exhibits more limited ambition; reforms have aimed to strengthen the capital buffers of large institutions and provide safeguards in cases of failure, with market mechanisms expected to provide longer-term incentives. The process, however, also marks a departure from the pre-crisis modus operandi: in a transnational context, there have been open disagreements both between the regulators and the regulated, and within the official community where national authorities with differing financial crisis experiences have put forward different preferences on TBTF.

In the past, large, global financial conglomerates had been considered adequately sophisticated in their techniques to be allowed lower capital buffers by the markets and eventually by the banking standards of Basel II, as designed by the BCBS (Tarullo 2008). The regulatory use of these advanced models, however, was also supported by an implicit guarantee of government assistance or bail-out. 'When failures are systemic, the danger is that one will end up with a morally disciplined but totally 
devastated economy' (Goodhart in CSFI 2009, 35), a point echoed by public officials after the Lehman Brothers fallout: 'it was a mistake not to save Lehman'. (3) With TBTF in the spotlight, the size of financial institutions was, if anything, increased in the immediate aftermath of the crisis as crisis management and consolidation in the financial sector led to ever larger financial institutions through the absorption of failing institutions by better-performing ones. In the regional setting of the European Union, the aspiration to achieve EU-wide banks (and thus, large banks) further strengthened this trend (Posner and Véron 2010). Yet for Andrew Haldane, Executive Director of Financial Stability at the Bank of England and a practitioner operating as a change agent in the reform process, 'size matters. Historically, the safety net was perceived to be fur-lined for those of a certain size' (Haldane 2009, 27). Sheila Bair, former Chair of the US Federal Deposit Insurance Corporation, found this especially troubling in light of the few advantages that size carries in terms of economies of scale, risk diversification or market access (Bair 2009).

How has this concern about size translated into policy? Reform has focused not on reducing size per se but on managing the complexity of TBTF institutions by clarifying criteria that make them 'systemically important', introducing living wills and a hierarchy of creditors in case of failure, and strengthening resolution regimes across borders. The practice of TBTF reform exhibits four features. First, policies do not challenge pre-crisis ideas about bank functions; financial institutions can continue to follow established practices as long as they are prepared to pay a premium for doing so. Second, the ideas shaping the debate about the regulatory treatment of TBTF institutions within the FSB originate in the same pool of experts. Third, no new mechanisms of regulation are introduced; the reformed regulatory treatment is to be based on a pre-crisis mix of standards, capital buffers and market discipline. The final feature constitutes the greatest break with past practice; the development of TBTF criteria has led to the production of a list of financial institutions, 'Global Systemically Important Financial Institutions' or G-SIFIs, that are consequently formally acknowledged to be systemically important in a transnational context.

How do the reforms satisfy formal constituencies? For the public officials who are members of the FSB, standards are created that recognise a special category of financial institutions and measures are put in place to better deal with failure. The threat to the sovereign, however, is not addressed. This is especially significant in light of research that indicates that the size of the financial sector, after a certain point, is detrimental to a country's economic growth (Cecchetti and Kharoubbi 2012). For the private sector and large financial institutions, the cost of reform is high in terms of unwanted extra capital requirements, though by being formally designed TBTF, the implicit safety net available to those institutions is reinforced. And for experts seeking reform on the basis of solid science, 
despite the introduction of innovations, the process has merely tweaked existing practices. This failure to satisfy formal constituencies can be explained in the transnational context, where constituencies are not strictly defined but diffuse. (4) There is bargaining among the actors (public and private) whose approval is needed for policy to go through, i.e. they are transnational veto players. The bargaining refers to which ideas are available for discussion and where they originate.

The type of expert ideas dominating reform discussions and ultimately affecting the practice of reform suggests a mode of policy emphasising compromise and trial and error. As Lindvall (2009) argues (in a domestic context) expert ideas exert influence over policy instruments, not policy objectives. They can thus settle the parameters of the feasible even as the reform goals of the experts providing the ideas (reforms based on good science) remain distinct from those of actors with formal policy functions. Expert distinctions over reform ideas are also embedded in professional peer networks that select what issues to prioritise and what issues should be excluded from discussions (Seabrooke and Tsingou 2014). Viewing the practice of reform through transnational veto players explains the role of expert ideas in the narrow definition of available policy instruments and accounts for the modest character of reform.

\section{TBTF and the practice of reform (5)}

The TBTF problem in its global dimension drew a great deal of attention in the reports that provided assessments of the crisis and recommendations for reform (High Level Expert Group 2009; Financial Services Authority 2009 among others) but limited practical guidance. (6) The reform impetus came from the bail-outs and the politicisation of the financial crisis, with G-20 leaders undertaking to address TBTF and to match regulatory standards to the costs of failure of those institutions (G-20 2009). The production of specific criteria and key proposals to address these issues just two years later testify to the importance accorded to TBTF.

TBTF financial institutions are commonly understood to have three key characteristics: they are very large in relation to world assets; they are especially large in relation to individual sovereigns; and their concentration is increasing. (7) What makes them problematic beyond relative measures of size is that their activities are diversified and complex, and that any cost savings derived from diversification have been offset by greater risk-taking. Post-crisis, they are also said to distort competition, having received the bulk of bail-out support (Goldstein and Véron 2011).

Matching these characteristics, there are three agreed objectives in reform activity (Cecchetti 2011): reducing the probability of failure of global systemically important banks; reducing the extent or 
impact of their failure; and levelling the playing field by reducing their competitive advantages in funding markets. For Paul Volcker, former Chairman of the Federal Reserve Board and an active grandee in financial policy networks, 'each is difficult intellectually, operationally, and politically, but progress in these areas is the key to effective and lasting financial reform' (Volcker 2011, 16). To achieve this, the reform process of the regulatory treatment of TBTF has proceeded along a twopronged approach, coordinated by the FSB, whose members have been the agenda-setters in the process. First, the FSB, alongside the BCBS, developed criteria that identify Systemically Important Financial Institutions (G-SIFIs at the global level). Second, the FSB is leading work on resolution regimes. The paper examines both elements of this approach in turn.

First published in late 2011 (BCBS 2011; FSB 2011a), the criteria determining G-SIFIs aim to provide a straightforward and consistent methodology for assessment and regulatory requirements. The criteria do not address TBTF per se, a relative concept and as previously discussed, often an ex post assessment. Instead, they identify five categories of indicators: (i) size; (ii) interconnectedness; (iii) availability or lack thereof of substitutes or financial institution infrastructure for services provided; (iv) global (cross-jurisdictional) activity; and (v) complexity. Financial institutions deemed G-SIFls according to this methodology will be subject to additional loss absorbency requirements (from 1 to 2.5 percentage points over the 7\% in equity capital banks must hold from 2019 under Basel III) and greater supervisory expectations. Identified G-SIFIs in late 2014 will be affected, with additional requirements phased in from 2016 and to be fully implemented in 2019 alongside Basel III requirements (FSB 2013). An original list of twenty-nine G-SIFIs (all global systemically important banks or G-SIBs) was produced in late 2011, and updated to twenty-eight in 2012. (8) Both the list and the methodology are dynamic by design. Ongoing data collection exercises until 2019 are to make the method more robust. Technical adjustments are expected as the indicators are relative: size is judged in relation to the banking sector and the average size of a large sample of banks (as determined by Bank for International Settlements data collection). The formal purpose of the exercise is to ensure that an appropriate framework is in place that acknowledges the special role of these institutions. The more enthusiastic regulatory proponents expect the process to incentivise firms not to be on the list or to move down the systemic sub-categories. If this initiative is to actually reduce the size of institutions, there is an accompanying assumption that the banking sector as a whole will shrink.

The reaction to the criteria and published list was mixed. There is little disagreement about size as an indicator, but analysts argue that all five types of indicators are essentially about size. Once G-SIFI criteria were to be made public, there was no controversy over naming G-SIFls either, the 
understanding being that market mechanisms would have identified TBTF institutions through funding discounts and credit rating upgrades (Goldstein and Véron 2011, 21). However, there was extensive scepticism about the policy's potential to change incentives and behaviour. Among the official community, TBTF reforms were expressly pushed by authorities from countries whose financial sector holds an especially important share of GDP (notably Switzerland and the UK), and followed more timidly by countries whose financial sectors were less overwhelmingly affected by the crisis. (9) This matches findings at the comparative domestic level linking regulatory reform activity and financialisation (Young and Park 2013). There has also been open disagreement between the official and private sectors, with the Institute of International Finance (IIF) a strong opponent of developments, primarily based on competitiveness arguments (IIF 2010a). That said, selected reactions on behalf of designated G-SIFIs suggest that the trade-off between additional surcharges and a more formalised TBTF status is acceptable, at least to some: Nordea's head of investor relations noted that 'it should be positive for Nordea to be declared a G-SIFI as this means the bank is 'too big to fail' and that could facilitate funding', while the JP Morgan Chief Executive stated that 'the status could mean more business from the bank as customers look for strong counterparties, but that the higher cost of holding the extra capital could lead it to sell assets it might otherwise have kept on its books' (reported in Haddon 2011).

The second element of the approach focuses on resolution regimes (FSB 2011b) and especially the links between effective resolution regimes and improving G-SIFI resolvability. This work is on recovery and resolution plans, including identifying critical functions and ways to preserve them; resolvability assessments; action to improve resolvability, consisting of information, bail-in debt and improvements in structure and operations. In addition, institution-specific cross-border cooperation agreements for G-SIFIs, and Crisis Management Groups for the relevant home and host authorities of G-SIFIs are being developed. Within the broad rubric of recovery and resolution, key components include living wills, that is, institutions' contingency plans in case of stress or failure (Huertas and Lastra 2011), as well as bail-ins, arrangements that would enable the resolution of a G-SIFI with limited recourse to public finances by triggering write-downs or conversion of unsecured and uninsured debt into equity. The work on recovery and resolution regimes is ongoing, especially the specific design features of these regimes but there has been less confrontation and controversy surrounding this part of the reform process and at the outset, there was broad agreement between the official and private sectors in Basel (IIF 2010b). Insider criticisms merely stress the importance of integrating the two elements of the approach (Weistroffer 2011). 
Having established the key framework for TBTF reform, it is possible to examine how the practice of reform is shaped. The parameters are mostly defined by ideational blockages, as the cost of the financial crisis and of saving TBTF institutions has substantially reduced actors' financial resources. This is not to say that resources do not matter. Among private actors, the sheer size of the G-SIFIs is a source of strength that makes securing their approval of reform more significant: a financial institution 'too scary to fail' (Johnson 2011) becomes a veto player in the reform process. The official sector too has access to resources, through the additional institutional capacity of the revamped FSB. With its G-20 mandate, the FSB has been decisive in the pace and scope of reform, widely perceived to have pursued both an institutional and personnel 'self-interest' by establishing its role as standard-setting coordinator and promoting the ambitions of its Chair, Mario Draghi (who went on to head the European Central Bank). (10) The FSB is also acknowledged to have built an expert profile on TBTF, particularly through the Chair of the relevant Working Group, Eva Hüpkes, a specialist in this field. (11)

Furthermore, in terms of resources, the designation of particular institutions as G-SIFIs reinforces their importance. Named G-SIFIs become more proactive and have different representation needs than smaller institutions; this in turn affects their involvement in both the IIF, and other lobbying organisations. The process changes actor interactions within the private sector and serves to produce more transnational players. What makes them veto players in this instance is not an act of approval or veto regarding the process of designating G-SIFls or the specific criteria but rather, potential veto acts regarding their own activities and risk-taking. Their risk-taking may become more expensive, but G-SIFIs have become de facto TBTF. There is some evidence that rating agencies have revised their assessments of implicit TBTF support, even though 'it will understandably take time to fully establish the credibility of the new framework in addressing TBTF' (FSB 2013, 23). But at the same time, the designation of G-SIFI, and the detailed assessment of what makes an institution so, makes this group of financial firms more important in policy debates, especially while the details of resolution plans are being finalised and the big banks continue to grow bigger. The functions remain unchanged but the special status is reinforced. In this context, the transgovernmental network of the FSB cannot ignore the importance of approval or veto of G-SIFIs in subsequent policy decisions, while lobby groups such as the IIF need to adjust their strategies to cater for the differing needs of G-SIFIs and others.

To fully grasp the importance of transnational interactions, however, and understand how actors operate as transnational veto players in the practice of reform, we need to consider the genealogy of reform ideas and the implicit ideological blockages in place. Policy ideas such as G-SIFI criteria and 
the list, living wills and bail-ins were not particularly mature prior to being discussed in Basel (at the FSB or BCBS). The G-SIFI list idea in particular was a big conceptual leap, (12) not so much in its methodology but in the formal classification and designation of specific institutions and the potential to accord them automatic TBTF status. The idea first appeared in a US Treasury paper (2009) and evolved quickly into policy. As for living wills, it is an idea developed by Thomas Huertas, at the time of the UK Financial Services Authority, who advocated a document akin to one used for a severely ill patient which would comprise a recovery capital plan, a recovery liquidity plan and a contingent resolution plan, including details on specific management actions (Huertas 2009). He first aired this idea at a conference of the Financial Markets Group of the London School of Economics. Finally, the idea of bail-ins originates in the work of current and former Credit Suisse executives, Paul Calello and Wilson Ervin (2010; see also Tett 2010). Looking to use tools in operation in other industries, Calello and Ervin proposed a procedure which 'would give officials the authority to force banks to recapitalise from within, using private capital, not public money', illustrating their proposal with an alternative Lehman Brothers scenario. (13) In brief, though these ideas constitute a departure from pre-crisis principles, they have been developed, promoted and ultimately adopted by actors acceptable to all participants in the policy process, i.e. all transnational veto players. Although the FSB was formal agenda-setter and ultimate adopter, the transnational interactions of members with official, private and expert counterparts meant that new thinking in the practice of reform built on ideational bargaining on the feasible. Ideas that threatened the status quo in changing the nature of banking activities such as limiting the use of financial derivatives (Rosengren 2009) were not followed through. The reform process is thus characterised by compromise, not because of the volume and pace of reform, which is extensive and swift in financial regulation terms, but in light of the ideational boundaries set by actors. Policy goals derived from defined formal constituencies are compromised in the transnational settings where global banking standards are determined because of the need to satisfy a more diffuse constituency of peers and interlocutors.

\section{Conclusions}

This article has argued that the actors that practice financial reform in a transnational setting can be understood as transnational veto players whose approval is needed for change to take place. These actors conceive their constituency as diffuse, as they are not bound by their defined roles alone but guided by their transnational associations and interactions. This argument challenges accounts of the crisis re-establishing the importance of public and private distinctions. Relations between the regulators and the regulated appear more adversarial, and there is discussion of them operating in 
different ideational spheres, with the official sector exploring new policy ideas and embracing new notions and the private sector acting in a reactionary manner and exploiting timeframes for implementation. In this context, it is tempting to use the language of change agents and veto players to describe the activities of the public and the private sector respectively. Yet this article shows that this would be analytically and practically misleading when we examine transnational activity. In that context, the pool of permissible ideas for change is determined by the interaction of public and private actors. These ideas do not challenge the basic functions of banks and are generated and turned into policy practice by actors who remain informed by pre-crisis and enduring transnational policy interactions.

The concept of transnational veto players serves as a device for understanding these transnational policy dynamics and the importance of ideational blockages. It is therefore a useful concept to adapt to a transnational setting as it helps illuminate the policy options and pool of reform ideas actors draw upon in the making of policy; it also explains why the policy goals of these actors, whether they are public or private, are not derived from their formal associations alone. The concept thus adds explanatory power to accounts of transnational regulatory interactions. This is all the more important as transnational interactions ultimately generate the global rules and standards that determine financial governance and practice.

In the study of TBTF reform, the concept is especially pertinent. TBTF is a reform area where harmonised regulation is desirable and thus global standards matter, yet it is also a source of inherent risk for any one national financial system if an institution poses a threat to the sovereign. Minimising or neutralising such risk is therefore an objective of reform. The practice of reform indicates, however, that the financial institutions that are the target of changed regulatory standards also need to be on board. The interactions between the different actors direct a compromise mode of policy that ensures that the ideational parameters of reform debates are acceptable to all actors. In the specific case of TBTF, one particular reform strand, the articulation of criteria that led to the publication of the G-SIFIs list, had an additional spillover effect. To be part of the list entails a higher cost in terms of reserve requirements but also a notional seat at the policy table. The importance of these financial institutions is reinforced through the TBTF exercise, potentially strengthening their veto power and semi-formalising their policy role in future reform rounds. This has consequences for the domestic level of policy-making too if they can 'hold the state to ransom'.

\section{Notes}


1. This point was repeatedly expressed in research interviews with practitioners at the start of the crisis. Making regulation independent of politics was a key priority for a senior generation of officials. Their aim was to minimise political influence and interference in the mechanisms of markets for short-term electoral purposes. Author interview with former Minister of Finance (confidential), October 2008.

2. Author interview with Central Bank official (confidential), October 2009.

3. Author interview with Central Bank governor (confidential), June 2009.

4. Note that this does not suggest a clear dichotomy between defined and diffuse but rather, implies that we need to look beyond the formal to understand what makes a constituency in a transnational setting.

5. The empirics in this section have been corroborated and expanded through research interviews in the official and private sector (financial institutions and umbrella lobbying organisations). Interviews were conducted with practitioners based primarily in the UK and US, but also countries without FSB representation (Denmark and Sweden, although the latter is represented at the BCBS). The interviews took place in February-April 2012.

6. Bair (2012) is an exception.

7. The analogies deployed to depict these financial institutions are dramatic, including 'Global Godzillas' (Sheng 2011). The increased concentration is backed by analysis by Goldstein and Véron (2011) which shows that the levels of concentration were greater in 2009 than in 2006.

8. The full 2011 list was: Bank of America, Bank of China, Bank of New York Mellon, Banque Populaire, Barclays, BNP Paribas, Citigroup, Commerzbank, Credit Suisse, Deutsche Bank, Dexia, Goldman Sachs, Group Crédit Agricole, HSBC, ING Bank, JP Morgan Chase, Lloyds, Mitsubishi UFJ, Mizuho, Morgan Stanley, Nordea, Royal Bank of Scotland, Santander, Société Générale, State Street, Sumitomo Mitsui, UBS, Unicredit Group, Wells Fargo. A revised list in 2012 saw the addition of BBVA and Standard Chartered and the removal of Commerzbank, Dexia and Lloyds. In 2012, each institution was placed into provisional buckets corresponding to the required level of additional loss absorbency.

9. The pre-crisis coalitions (cf. Quaglia 2012) have thus been resilient though those most scarred early in the financial crisis have been keener to move fast and go further.

10. Research interview with former UK Financial Services Authority official (confidential), April 2012. 
11. Research interview with UK member of the Financial Stability Board (confidential), April 2012. Hüpkes (2009) on resolution is an example of such expert work.

12. I thank Nicolas Véron for his input in developing this point.

13. The ideas' genealogy account was corroborated in the research interviews. Though these ideas were 'new' in terms of global banking regulation, they were sometimes latent: 'bail-ins' more broadly, for instance, were discussed in past crises (Latin American and Asian crises).

\section{References}

Baker, A. (2013) 'The new political economy of the macroprudential ideational shift', New Political Economy, 18:1, 112-39.

Basel Committee on Banking Supervision (2011) Global systemically important banks: Assessment methodology and the additional loss absorbency requirement - Rules text, Basel.

Bair, S. (2009) 'Regulating and resolving institutions considered "too big to fail"', Statement before the Committee on Banking, Housing and Urban Affairs, US Senate, 6 May.

Bair, S. (2012) Bull by the Horns (New York: Free Press).

Barth, J., Caprio, G. Jr and Levine, R. (2012) Guardians of Finance: Making Regulators Work For Us (Cambridge, MA: The MIT Press).

Béland, D. and Orenstein, M.A. (2010) 'Transnational actors and public policy', JSGS Working Paper Series 5.

http://www.schoolofpublicpolicy.sk.ca/ documents/ publications reports/working paper series/ WPS5 Beland AUGUST2010.pdf

Blyth, M. (2002) Great Transformations - Economic Ideas and Institutional Change in the Twentieth Century (Cambridge: Cambridge University Press).

Botzem, S. (2012) The Politics of Accounting Regulation: Organizing Transnational Standard Setting in Financial Reporting (Cheltenham: Edward Elgar).

Büthe, T. and Mattli, W. (2011) The New Global Rulers: The Privatization of Regulation in the World conomy (Princeton, NJ: Princeton University Press).

Calello, P. and Ervin, W. (2010) 'From Bail-out to Bail-in', The Economist, 28 January.

Cecchetti, S.G. (2011) 'How to cope with the Too-Big-To-Fail problem?', Comments prepared for the 10th Annual Conference of the International Association of Deposit Insurers, 'Beyond the Crisis: The Need for a Strengthened Financial Stability Framework', Warsaw, Poland, 19 October.

Cecchetti, S.G. and Kharroubi, E. (2012) 'Reassessing the impact of finance on growth', BIS Working Paper No 381, Bank for International Settlements.

Centre for the Study of Financial Innovation (CSFI) - Multiple authors (2009) Grumpy Old Bankers: Wisdom From Crises Past (London: CSFI). 
Drezner, D. (2007) All Politics is Global - Explaining International Regulatory Regimes (Princeton, NJ: Princeton University Press).

Financial Services Authority (2009) The Turner Review: A Regulatory Response to the Global Banking Crisis, London.

Financial Stability Board (2011a) Policy Measures to Address Systemically Financial Institutions, Basel.

Financial Stability Board (2011b) Key attributes of Effective Resolution Regimes for Financial Institutions, Basel.

Financial Stability Board (2013) Progress and Next Steps Towards Ending 'Too-Big-To-Fail' - Report of the Financial Stability Board to the G-20, Basel.

G-20 Leaders (2009) Leaders Statement, Pittsburgh summit. 24-25 September.

Goldstein, M. and Véron, N. (2011) 'Too Big To Fail - The transatlantic debate', Bruegel Working Paper 2011/03.

Haas, P. (1992) 'Introduction: Epistemic communities and international policy coordination', International Organization, 46:1, 1-35.

Haddon, M. (2011) 'Global banks named as 'Too Big To Fail", Marketwatch, 4 November. http://www.marketwatch.com/story/global-banks-named-as-too-big-to-fail-2011-11-04

Haldane, A. (2009) 'Rethinking the financial network', Speech delivered at the Financial Student Association, Amsterdam, April.

Helleiner, E. (2011) 'The limits of incrementalism: The G20, the FSB, and the international regulatory agenda', Journal of Globalization and Development, 2:2, 1-19.

High Level Group on Financial Supervision in the EU (2009) Report, Brussels.

Huertas, T. (2009) 'Too big to fail, too complex to contemplate: What to do about systemically important firms', Speech delivered at the Financial Markets Group Conference, London School of Economics. London, 15 September.

Huertas, T. and Lastra, R. (2011) 'Living Wills', Estabilidad Financiera 21, Banco de España, 23-39.

Hüpkes, E. (2009) 'Special bank resolution and shareholders' rights: balancing competing interests', Journal of Financial Regulation and Compliance, 17:3, 277-301.

International Monetary Fund (2009) Initial Lessons of the Crisis, Washington, DC.

Institute of International Finance (2010a) Systemic Risk and Systemically Important Firms - An Integrated Approach, Washington, DC.

Institute of International Finance (2010b) A Global Approach to Resolving Failing Financial Firms: An Industry Perspective, Washington, DC.

Johnson, S. (2011) 'The challenge of large complex financial institutions', Remarks made at the Second Conference of the Institute for New Economic Thinking, Bretton Woods, 9 April. http://www.youtube.com/watch?v=-GmBoJ7qHYg\&feature=player embedded

Lindblom, C. (1959) 'The Science of “Muddling Through"', Public Administration Review, 19:2, 79-88. 
Lindvall, J. (2009) 'The Real but Limited Influence of Expert Ideas', World Politics, 61:4, 703-730.

Mahoney, J. and Thelen, K. (2010) 'A theory of gradual institutional change', in J. Mahoney and K. Thelen (eds) Explaining Institutional Change: Ambiguity, Agency, and Power, 1-37 (Cambridge: Cambridge University Press).

Marcussen, M. (2009) 'Scientization of central banking: The politics of a-politicization', in K. Dyson and M. Marcussen (eds) Central Banking in the Age of the Euro, 373-390 (Cambridge: Cambridge University Press).

Moschella, M. and Tsingou, E. (2013a) 'Regulating finance after the crisis: Unveiling the different dynamics of the regulatory process', Regulation and Governance, doi:10.1111/rego.12032.

Moschella, M. and Tsingou, E. (eds) (2013b) Great Expectations, Slow Transformations: Incremental change in post-crisis regulation (Colchester: ECPR Press).

Pagliari, S. (ed.) The Making of Good Financial Regulation: Towards a Policy Response to Regulatory Capture (London: International Centre for Financial Regulation).

Pierson, P. (2000) 'Increasing returns, path dependence, and the study of politics', American Political Science Review, 94:2, 251-67.

Posner, E. and Véron, N. (2010) 'The EU and financial regulation: Power without purpose?', Journal of European Public Policy, 17:3, 400-415.

Porter, T. and Ronit, K. (2006) 'Self-regulation as policy process: The multiple and criss-crossing stages of private rule-making', Policy Sciences, 39, 41-72.

Quaglia, L. (2012) 'The "old" and "new" politics of financial services regulation in the European Union', New Political Economy, 17:4, 515-535.

Rethel, L. and Sinclair, T. (2012) The Problem with Banks (London: Zed Press).

Rosengren, E. (2009) 'Challenges in Resolving Systemically Important Institutions', Speech at The Institute of Regulation and Risk North Asia, Hong Kong, 5 May.

Rothmayr, A. and Saint-Martin, D. (2011) 'Half a century of "muddling": Are we there yet?', Policy and Society, 30, 1-8.

Schmidt, V. (2002) The Future of European Capitalism (Oxford: Oxford University Press).

Seabrooke, L. and Tsingou, E. (2014) 'Distinctions, Affiliations, and Professional Knowledge in Financial Reform Expert Groups', Journal of European Public Policy 21:1, forthcoming.

Sheng, A. (2011) 'Too big to fail, too big to jail', Paper presented at the Second Conference of the Institute for New Economic Thinking, Bretton Woods, 9 April.

Simmons, B. (2001) 'The international politics of harmonization: The case of capital market regulation', International Organization, 55:3, 589-620.

Streeck, W. and Thelen, K. (eds) (2005) Beyond Continuity: Institutional Change in Advanced Political Economies (Oxford: Oxford University Press).

Tarullo, D. (2008) Banking on Basel: The Future of International Financial Regulation (Washington, DC: Peterson Institute for International Economics). 
Tett, G. (2010) “Bail-in' will save the taxpayer from the bailout', Financial Times, 15 July.

Tsebelis, G. (2000) 'Veto players and institutional analysis', Governance, 13:4, 441-74.

Tsebelis, G. (2002) Veto Players: How Political Institutions Work (Princeton, NJ: Princeton University Press).

US Treasury (2009) Financial Regulatory Reform - A New Foundation: Rebuilding Financial Supervision and Regulation, Washington, DC.

Volcker, P. (2011) 'Three years later - Unfinished business in financial reform', The William Taylor Memorial Lecture No. 13, The Group of Thirty, Washington D.C.

Weistroffer, C. (2011) 'Identifying systemically important financial institutions', Deutsche Bank Research, 11 August.

Young, K. (2012) 'Transnational regulatory capture? An empirical examination of the transnational lobbying of the Basel Committee on Banking Supervision', Review of International Political Economy, 19:4, 663-688.

Young, K. and Park, S.H. (2013) 'Regulatory Opportunism: Cross-national patterns in national banking regulatory responses following the global financial crisis', Public Administration, 91:3, 561-581. 
Figure 1: Transnational veto players, constituencies, and policy modes

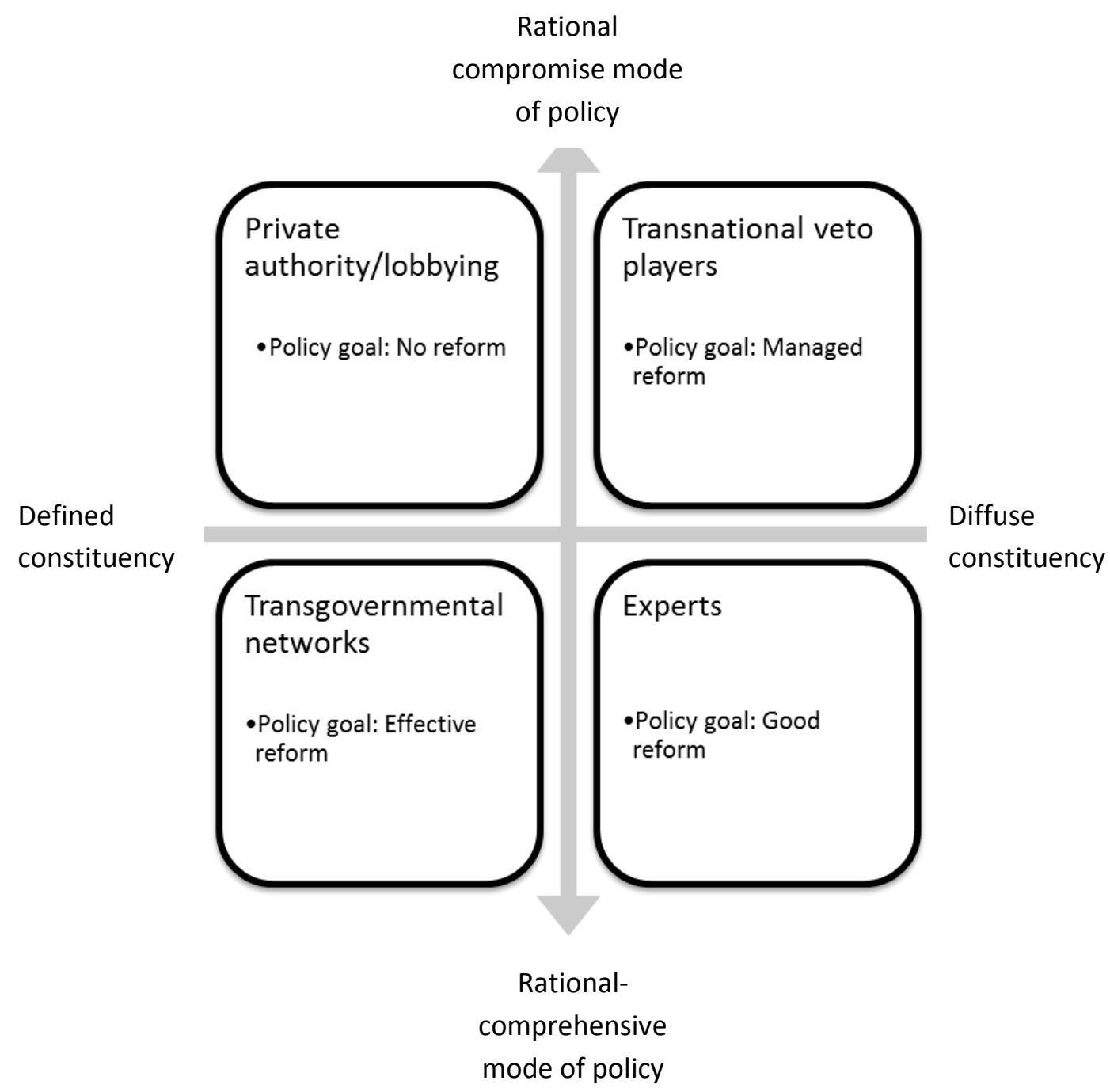


Table 1: The practice of reform and traditional explanations

\begin{tabular}{|l|l|l|l|}
\hline & $\begin{array}{l}\text { Transgovernmental } \\
\text { networks }\end{array}$ & $\begin{array}{l}\text { Private authority / } \\
\text { Lobbying }\end{array}$ & Experts \\
\hline Formal constituency & National governments & Financial institutions & Peers \\
\hline Reform policy goals & $\begin{array}{l}\text { Stability / } \\
\text { Development of good } \\
\text { standards }\end{array}$ & Profit and rent-seeking & $\begin{array}{l}\text { Implementation } \\
\text { of good science }\end{array}$ \\
\hline Key constraints & $\begin{array}{l}\text { Electoral politics / } \\
\text { Cost of financial crisis }\end{array}$ & Reduced resources & Discredited expertise \\
\hline
\end{tabular}

